\title{
A 28-year-old pregnant woman with severe toothache
}

\section{Md. Joynal Abdin and Mozammal Hossain}

\section{Article Info \\ Department of Conservative Dentistry and Endodontics, Faculty of Dentistry, \\ Bangabandhu Sheikh Mujib Medical \\ University, Shahbag, Dhaka, Bangladesh \\ For Correspondence: \\ Md. Joynal Abdin \\ j_abdin02@yahoo.com \\ Received: \\ Accepted: \\ Available Online: \\ 18 December 2019 18 February 2020 \\ 19 February 2020 \\ ISSN: 2224-7750 (Online) \\ 2074-2908 (Print) \\ DOI: 10.3329/bsmmuj.v13i1.44502}

Keywords: Pregnancy; Pulpitis; Root canal; Toothache

Cite this article:

Abdin MJ, Hossain M. A 28-year-old pregnant woman with severe toothache. Bangabandhu Sheikh Mujib Med Univ J. 2020; 13: 31-34.

\section{Copyright:}

The copyright of this article is retained by the author(s) [Atribution CC-By 4.0]

Available at:

www.banglajol.info

A Journal of Bangabandhu Sheikh Mujib Medical University, Dhaka, Bangladesh

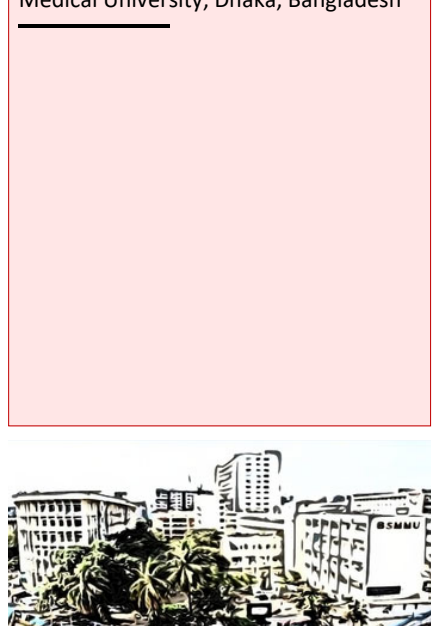

\section{Presentation of Case}

Dr. Md. Joynal Abdin (Assistant Professor): A 28year-old woman came with severe pain on the lower left quadrant of the mouth. She already had an orthopantomogram (panoramic view) six months back which showed a dislodged temporary filling on the lower left second premolar (Figure 1A). The woman also told that she had six weeks of pregnancy. The patient also stated that she had pain and sensitivity on the same tooth at about one year back and went to a local dental surgeon. The dental surgeon at that time put a filling on that tooth. For three days, she could not sleep at night due to pain in that region. She did not have any other physical problem and did not take any other medicine.

After examining the patient, it was found that the patient had gross caries and pain on the lower left second premolar or second bicuspid. She also had caries on lower right first and second molar teeth. There were deposition of calculus and dental plaque in the gingiva. The patient was very upset of having such severe pain during her first issue of pregnancy and she wanted to get relieve from such intolerable pain.

During the first visit, the patient was assured that it was good to have dental treatment during her pregnancy to live with a comfortable life. In fact, without endodontic procedure, there are only NSAIDs to relieve her pain. But, non-steroidal anti-inflammatory drugs are typically contraindicated in pregnancy especially in dental pain. 1,2 Accordingly, the patient prescribed a safe antibiotic amoxicillin $500 \mathrm{mg} 8$ hourly for 5 days. But, antibiotics like tetracycline are contraindicated as those may cause yellow grey brown discoloration of teeth and enamel hypoplasia of her offspring. Non-steroidal antiinflammatory drugs like diclofenac, ibuprofen, ketoprofen, naproxen, etc were avoided as these drugs might cause miscarriage. Instead NSAID, only paracetamol was given. The patient was asked to come for root canal treatment on the next day in second visit.

In the second visit, the patient was taken extra care to seat on the dental chair with her buttock touching with chair avoiding cross leg. Longtime seating with the same position was avoided. Lignocaine hydrochloride (2\%) was used as local anesthetic to block the inferior alveolar nerve and infiltration into lower left second premolar tooth. The previously filled temporary filling material and carious lesion was completely removed with a TC round bur. The access cavity was done towards the vertical axis of the pulp chamber. After access to the pulp chamber, the roof of the pulp chamber was completely removed according to the anatomical shape of the chamber with a fissure bur (TF11). The necrotic pulp tissue, debris was cleaned from the pulp chamber with an excavator. Sodium chloride solution $(0.9 \%)$ was used to flash out the chamber. The canal orifice was found out on the floor of the pulp chamber and the canals were shaped. Then introducing a KFile, a diagnostic X-ray was taken to measure the length of the canal (Figure 1B). The working length was determined. After the determination of working length, the canal (single) was widened using the Files up to \#60. The canal was continuously irrigated with a 5\% sodium hypochlorite solution especially to

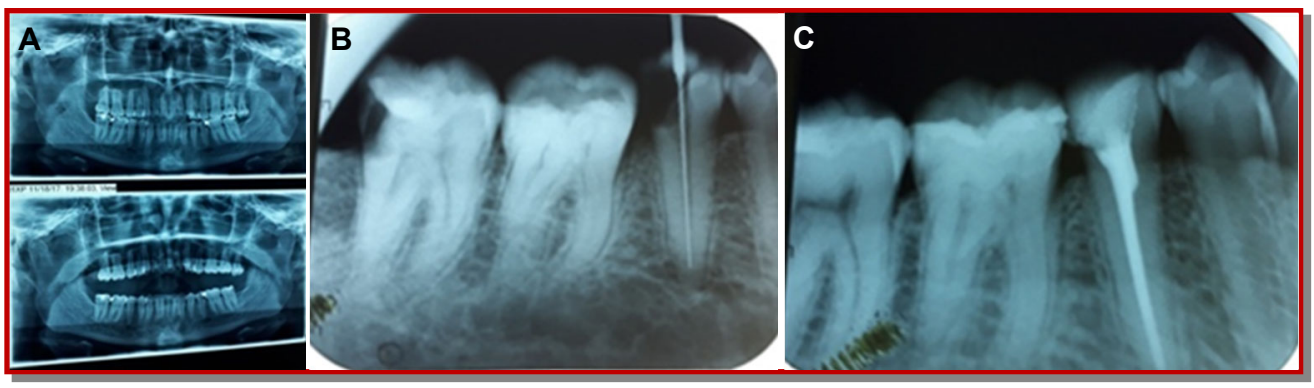

Figure 1: (A) Orthopantomogram X-ray showed dislodged temporary filling on lower left second premolar; (B) A diagnostic X-ray after inserting a file into the root canal to measure the canal length; (C) The canal was sealed with gutta percha point and sealer 
remove the smear layer. During the whole procedure, the precaution was taken so that the bacteria from saliva and oral cavity can't get into the canal and sodium hypochlorite solution can't get outside the canal.

Then the canal was dried with paper point 60 and immediately sealed with a master cone gutta-percha (\#60) and root canal sealer (sealapex) (Figure 1C). Lateral condensation was done with gutta-percha point \#20 and finally, a temporary restoration was done with a temporary filling material zinc oxy phosphate cement.

\section{Provisional Diagnosis}

Irreversible pulpitis

\section{Differential Diagnosis}

\section{Reversible pulpitis}

Dr. Ridwana Kawsar (MS Resident): There are cases of pulpitis when there isn't contamination of pulp with bacteria and can be preserved by some pulp capping or lining materials. 3,4 Here, most of the occlusal pulp tissue was necrosed and contaminated. So, the pulp can't be preserved and there is no chance to be reversed into a normal pulp.

\section{Periodontitis}

Dr. Kawsar: During pregnancy, there is an increased chance of gingivitis which may lead to periodontitis.., 6 But, in periodontitis, there should have increased periodontal pocket and tooth mobility. Here, there is no increased periodontal pocket depth and tooth mobility.

\section{Periodontal abscess}

Dr. Kawsar: Due to chronic cases of the non-vital teeth, there is a chance of periodontal abscess.7,8 But, there should have swelling and formation of pus inside. Here, there is no swelling and pus accumulation.

\section{Dr. Abdin's Diagnosis}

Irreversible pulpitis on lower left second premolar of a pregnant woman

\section{Discussion}

Dr. Abdin: Pregnancy is a lifetime experience for a woman. It is indistinguishable when this opportunity would come to a woman. But, one should have a plan and preparation for that time to have a better experience and a healthy child. Beforehand, the woman should get all her physical problems solved. Because, pregnancy induces a state of increased susceptibility to certain intracellular pathogens,9, 10 including viruses, 11,12 intracellular bacteria, 13,14 due to hormonal change. So, there is an increasing tendency of gingivitis with other dental decaying. $\frac{15,16}{16}$ Especially, if there is an acute condition that hampers her life by giving stress and anxiety must be treated. 17,18 During pregnancy, the women become reluctant to take dental treatment and the dentist also gets hesitant to treat. Previously, it was thought that during pregnancy, no dental treatment should be taken. But, recently the idea is changed. Dental treatment during pregnancy can give a comfortable life status but without it, life is very much injurious to a woman. Especially, an acute problem must be treated without leaving it to be done after delivery. Also, routine dental work like cleaning, filling should be done during pregnancy but serious maxillofacial surgery can be avoided.

Pregnancy can be divided into three stages (trimester). Each trimester includes approximately three months. The first trimester is the most important part of the organogenesis and development stage.19, 20 Women should avoid any elective surgery during this time. But, once one gets an acute problem that is severe and makes life very restless must be treated but with every caution.21,22 This patient has a severe toothache in the six weeks of her pregnancy. It could be better if it could be neglected and done in the next trimester but it could give severe suffering and distress to the mother and at the same time to the fetus. So, the root canal treatment with all precautions was done for the woman. Time to time (12 and 20 weeks) ultrasonography was taken to exclude any fetus anomalies and nothing abnormally was detected. A healthy baby girl was delivered and the whole family is happy. Also, she is happy with her root canal therapy on the left second premolar.

\section{Follow-up}

Dr. Farhana Khatoon: (Assistant Professor, Obstetric, and Gynecology): The ultrasonography of 12 and 20 weeks revealed that there were no fetal anomalies. The healthy baby was born.

Dr. Tania Parveen (MS Resident): What could be the problem if this case was not treated during pregnancy?

Dr. Abdin: Yes, there are sayings to leave the dental treatment procedure for after delivery. The first important point is, there is no other good option to get rid of such unbearable pain except root canal treatment. Secondly, now-a-days the concept has been changed and pregnant women are recommended to dental treatment like root canal treat- 
ment, scaling, filling and even extraction to give her a comfortable life. 23,24 If not treated, there is a chance of periapical infection which may transmit into the brain even.

Dr. Tahmida Hoque (MS Resident): What may be the possible complications for dental treatment procedure in pregnancy?

Dr. Khatoon: There is evidence of premature babies of low birth weight due to periodontal disease in pregnant mothers. The premature baby has increased risk of diseases like cerebral palsy, eye and hearing trouble. $\underline{25,26}$ On the other hand, there is no evidence of complications after having a treatment like an endodontic therapy. Only a long time sitting in the same position of the pregnant mothers should be avoided, NSAIDs should be avoided, a minimum dose of lignocaine hydrochloride but not prilocaine should be used. Prilocaine has an increased tendency to cause methemoglobinemia of the fetus. 27,28

Dr. Kawsar: Is there any radiological hazard in the fetus of the mother?

Dr. Farzana Alam (Sonologist): Very high-level radiation like radiotherapy for cancer patient may have risks of miscarriage, birth defects. But, the dental Xrays are comparatively of very low levels which do not have any harmful effect on the body and similarly to an unborn baby. Moreover, fetus, pelvic area are not exposed to radiation during a dental Xray. Still, it is better to use a lead apron which covers the thyroid, abdomen and pelvic area. 29,30

\section{Final Diagnosis}

Irreversible pulpitis on lower left second premolar tooth of a pregnant woman

\section{References}

1. Monisha M, Elengickal TJ, Ram SKM, Madhu ML, Raghuveeran M, Pillai RR. Attitude and awareness of dentists practicing in Southern India toward non-steroidal anti-inflammatory drugs. J Pharm Bioallied Sci. 2019; 11(Suppl 2): 355-59.

2. Haas DA. An update on analgesics for the management of acute postoperative dental pain. J Can Dent Assoc. 2002; 68: 476-82.

3. Sultana R, Hossain M, Alam MS. Evaluation of clinical and radiological outcomes of mineral trioxide aggregate and calcium hydroxide as indirect pulp capping agents in the treatment of deep carious lesion of permanent teeth. Bangabandhu Sheikh Mujib Med Univ J. 2016; 9: 140-45.

4. Ali $\mathrm{H}$, Hossain M, Abdin J. A 42-year-old female with thermal sensitivity in the lower left first molar tooth. Bangabandhu Sheikh Mujib Med Univ J. 2018; 11: 231-35.
5. Corbella S, Taschieri S, Del Fabbro M, Francetti L, Weinstein R, Ferrazzi E. Adverse pregnancy outcomes and periodontitis: A systematic review and meta-analysis exploring potential association. Quintessence Int. 2016; 47:193-204.

6. Manrique-Corredor EJ, Orozco-Beltran D, LopezPineda A, Quesada JA, Gil-Guillen VF, CarratalaMunuera C. Maternal periodontitis and preterm birth: Systematic review and meta-analysis. Community Dent Oral Epidemiol. 2019; 47: 243-51.

7. Strafford KE, Shellhaas C, Hade EM. Provider and patient perceptions about dental care during pregnancy. J Matern Fetal Neonatal Med. 2008; 21: 63-71.

8. Michalowicz BS, DiAngelis AJ, Novak MJ, Buchanan W, Papapanou PN, Mitchell DA, Curran AE, Lupo VR, Ferguson JE, Bofill J, Matseoane S, Deinard AS Jr, Rogers TB. Examining the safety of dental treatment in pregnant women. J Am Dent Assoc. 2008; 139: 685-95.

9. Domeika M, Domeika K, Paavonen J, Mårdh PA, Witkin SS. Humoral immune response to conserved epitopes of Chlamydia trachomatis and human 60-kDa heat-shock protein in women with pelvic inflammatory disease. J Infect Dis. 1998; 177: 714-9.

10. Vigliani MB, Bakardjiev AI. Intracellular organisms as placental invaders. Fetal Matern Med Rev. 2014; 25: 332-38.

11. Nuriel-Ohayon M, Neuman H, Ziv O, Belogolovski A, Barsheshet Y, Bloch N, Uzan A, Lahav R, Peretz A, Frishman S, Hod M, Hadar E, Louzoun Y, Avni O, Koren O. Progesterone increases Bifidobacterium relative abundance during late pregnancy. Cell Rep. 2019; 27: 730-36.

12. Baud D, Greub G. Intracellular bacteria and adverse pregnancy outcomes. Clin Microbiol Infect. 2011; 17: $1312-22$

13. Olgun NS. Viral infections in pregnancy: A focus on Ebola virus. Curr Pharm Des. 2018; 24: 993-98.

14. Bonvicini F, Bua G, Gallinella G. Parvovirus B19 infection in pregnancy: Awareness and opportunities. Curr Opin Virol. 2017; 27: 8-14.

15. Kukletova M, Izakovicova Holla L, Musilova K, Broukal Z, Kukla L. Relationship between gingivitis severity, caries experience and orthodontic anomalies in 13-15-year-old adolescents in Brno, Czech Republic. Community Dent Health. 2012; 29: 179-83.

16. Hartnett E, Haber J, Krainovich-Miller B, Bella A, Vasilyeva A, Lange Kessler J. Oral health in pregnancy. J Obstet Gynecol Neonatal Nurs. 2016; 45: 565-73.

17. Raimann T. The ethics of dental treatment during pregnancy. J Am Dent Assoc. 2016. 147: 688-89.

18. Steinberg BJ, Hilton IV, Iida H, Samelson R. Oral health and dental care during pregnancy. Dent Clin 
North Am. 2013; 57: 195-210.

19. Mickal A, Panzer JD. The safety of lincomycin in pregnancy. Am J Obstet Gynecol. 1975; 121: 1071 -74 .

20. Al-Saleem AI, Al-Jobair AM. Possible association between acetazolamide administration during pregnancy and multiple congenital malformations. Drug Des Devel Ther. 2016; 10: 1471-76.

21. Steinberg BJ, Hilton IV, Iida H, Samelson R. Oral health and dental care during pregnancy. Dent Clin North Am. 2013; 57: 195-210.

22. Tettamanti L, Lauritano D, Nardone M, Gargari M, Silvestre-Rangil J, Gavoglio P, Tagliabue A. Pregnancy and periodontal disease: Does exist a two-way relationship? Oral Implantol (Rome). 2017. 27; 10: 112-18.

23. Chiodo GT, Rosenstein DI. Dental treatment during pregnancy: A preventive approach. J Am Dent Assoc. 1985; 110: 365-68.

24. Ngeow WC, Chai WL.Understanding the dental need and care during pregnancy: A review. Med J Malaysia. 1999; 54: 146-50.
25. Kurien S, Kattimani VS, Sriram R, Sriram SK, Prabhakar Rao VK, Bhupathi A, Bodduru R, Patil N. Management of pregnant patient in dentistry. J Int Oral Health. 2013; 5: 88-97.

26. Frey HA, Klebanoff MA. The epidemiology, etiology, and costs of preterm birth. Semin Fetal Neonatal Med. 2016; 21: 68-73.

27. Lee JM, Shin TJ. Use of local anesthetics for dental treatment during pregnancy: Safety for parturient. J Dent Anesth Pain Med. 2017; 17: 81-90.

28. Singh M. The pregnant dental patient. J Mass Dent Soc. 2012 ; 60: 32-34.

29. Liu QJ, Lu X, Zhao H, Chen S, Wang MM, Bai Y, Zhang SL, Feng JB, Zhang ZH, Chen DQ, Ma LW, Jia TZ, Liang L. Cytogenetic analysis in 16-year follow-up study of a mother and fetus exposed in a radiation accident in Xinzhou, China. Mutat Res. 2013; 755: 68-72.

30. Buch B, Fensham R, Maritz MP. An assessment of the relative safety of dental $\mathrm{X}$-ray equipment. SADJ. 2009; 64: 348-50. 